\title{
With the Application of Innovative Talents Training as the Goal of "Fermentation Technology" Excellent Course Group Construction
}

\section{Qun Wei ${ }^{a}{ }^{*}$, Sheng Zheng ${ }^{b}$, Da Yu Yuc, Qing Xiao Zhao ${ }^{d}$, Yue Hua Liu ${ }^{e}$ and Xiu Ting Zhang ${ }^{\dagger}$}

\author{
School of Chemical Engineering, Northeast Dianli University, Jilin, 132012, China

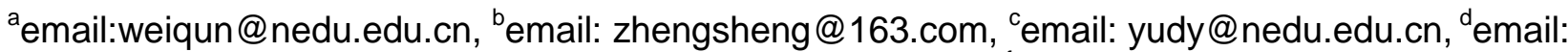 \\ zhaoqingxiao@163.com, eemail:liuyuehua@nedu.edu.cn, ${ }^{\dagger}$ email: zhangxiuting@163.com
}

Keywords: Fermentation technology; Course group; Application of innovative talents; Training; Target

\begin{abstract}
Objective: fermentation technology curriculum group is a backbone course of Bioengineering Specialty in our college, in the construction of excellent course groups also exist some problems, have great influence on students' practical ability cultivation of applied innovative; Methods: through the curriculum group construction, teaching team construction, optimizing the course contents and teaching methods and other aspects of the fermentation process of excellent course group construction; Results: the formation of fermentation technology course of a unified and efficient group through the above measures, explore the ways professional application type biological engineering innovative talents training, can improve the students ability of practice application of professional quality, engineering and scientific research innovation ability; Conclusion: through the course group construction, so that the students in the future employment and further studies have enough competitiveness.
\end{abstract}

\section{Introduction}

Fermentation technology curriculum group is a very practical subject, mainly including the technology of fermentation, amino acid technology, comprehensive experiment, biological process of biological engineering curriculum design and practice of curriculum and the practice teaching, relates to a comprehensive knowledge of Biochemistry, microbiology, chemical principles of many subjects such as biological engineering, is the backbone of the professional courses. Play an important role in the aspect of cultivating practical and innovative abilities of students [1].

\section{The Review of the Present}

A later biological engineering specialty in our college, although in recent years carried out a series of teaching reform, but there are still some defects in the process of training talents, especially some problems still exist in the construction of my professional fermentation technology excellent course group, mainly in the knowledge system of loose part teaching contents, the existence of overlapping phenomenon; teaching team the building of the contingent of teachers is not enough, there is no corresponding course group to form the stable; practice teaching in curriculum content could not meet the requirement of theory course, disjointed in content; teaching method and teaching means a single comparison, influence students' professional course learning effect. Have great influence on students' practical ability cultivation of Applied Innovative these problems, is not conducive to engineering and technical talents of all-round development of high-quality.

\section{The Reform Ideas}

Through the construction of excellent course group, the reform of teaching system, the selection of textbook series high level, to arrange the curriculum group teaching contents, course, avoid loose repetition enable students to high efficiency, organic learning of the professional courses. The optimization of teaching method, Arrange practice reasonable, strengthens the curriculum group of 
mutual connection between various courses; improve students' interest in learning. Strengthening the practical teaching links, the establishment of a stable base of practice teaching, the classroom and the factory the theoretical knowledge of the actual combination to cultivate students' ability [2], To improve students' comprehensive qualities and practical innovation ability, enhance students' competitiveness in the job market, so as to realize the training goal of our education.

\section{Reform Measures}

Curriculum Group Construction. The organic combination of each course, give full play to subject correlation and holistic and complementary, the completion of the four system as shown in table 1 .

Table 1 Curriculum group construction of four systems

\begin{tabular}{|c|c|c|}
\hline Serial number & Name & The main features \\
\hline 1 & $\begin{array}{l}\text { the theoretical system of } \\
\text { knowledge }\end{array}$ & $\begin{array}{l}\text { teaching hours and teaching } \\
\text { contents of each professional } \\
\text { course curriculum adjustment } \\
\text { in the group, to form a unified } \\
\text { and compact, orderly and } \\
\text { interrelated knowledge system } \\
\text { research discussion, }\end{array}$ \\
\hline 2 & teaching system & $\begin{array}{c}\text { collective lesson preparation, } \\
\text { teaching interaction }\end{array}$ \\
\hline 3 & practice teaching system & $\begin{array}{l}\text { the practice teaching, } \\
\text { comprehensive experiment and } \\
\text { course design organically, to } \\
\text { supplement the theory teaching } \\
\text { system }\end{array}$ \\
\hline 4 & $\begin{array}{l}\text { the extracurricular practice } \\
\text { innovation system }\end{array}$ & $\begin{array}{l}\text { pay attention to the } \\
\text { combination of theory and } \\
\text { practice teaching system of } \\
\text { extracurricular activities }\end{array}$ \\
\hline
\end{tabular}

The Construction of Teaching Team. The formation of the curriculum group instructor team, each course at least equipped with 1-2 experimental teachers 2-3 name theory teachers and, by establishing the combination of old and new professional teaching team with both old and new way.

Optimization Course Content. Set up with My School Characteristic Curriculum System. Bioengineering specialty in our college students employment mainly oriented to biological products production enterprises, analysis measures and solutions in the professional course teaching course content focuses on beer, fuel ethanol, amino acid, bio pharmaceutical and other production principle, process, equipment, production fault, the introduction of production examples, that the relationship between students clear professional courses and the future work, make the professional backbone course teaching has more practicability and pertinence, fully stimulate students interest in learning [3].

Teaching Syllabus and the Renewal of the Teaching Content. According to the construction of the goal as the center to applied innovative talents cultivation, the revised theory and practice teaching outline, clear teaching content and important knowledge, integrating the teaching content of the course of teaching, to avoid duplication, the general situation of introduction of biological engineering industry and the latest developments, the formation of a new teaching content system.

The Reform of Practice Teaching. The construction of comprehensive experimental teaching system of new biological process[4], The establishment of comprehensive experiment of biological technology across the curriculum, optimizing experiment content, increase the content of 
application, designing and research experiment[5], improve students' ability to use the theoretical knowledge, training students' initiative and innovation ability.

To change the pattern of practice teaching, the typical pays great attention to the choice of practice base [6], foster a stable base of practice teaching. The intern teachers in the process of recording under the factory practice teaching piece, the biological factory production process, equipment and production process of visual picture, let the students in practice in factories before watching the practice teaching piece, enhance the perceptual knowledge, and then with the problem of production practice. At the same time, encourage students to use the holiday to participate in corporate training and internship [7], through the practice to promote the understanding of the theoretical teaching content, training students' ability of innovation and practice.

\section{The Extracurricular Practice Research on Innovation System as Shown in Table 2.}

Table 2 extracurricular innovation system content

\begin{tabular}{|c|c|c|}
\hline $\begin{array}{c}\text { Serial } \\
\text { number }\end{array}$ & $\begin{array}{l}\text { Extracurricular innovation } \\
\text { form }\end{array}$ & Characteristic \\
\hline 1 & social practice activities & $\begin{array}{l}\text { participate in internal and external } \\
\text { social practice activities such as } \\
\text { environmental protection publicity, } \\
\text { volunteering, religion, work study } \\
\text { program, to enable students to contact } \\
\text { the society, exercise ability, broaden } \\
\text { their horizons }\end{array}$ \\
\hline 2 & $\begin{array}{l}\text { science and technology } \\
\text { competition }\end{array}$ & $\begin{array}{l}\text { in the school, municipal, provincial, } \\
\text { National Science and technology } \\
\text { competition, improve the } \\
\text { comprehensive quality of students }\end{array}$ \\
\hline 3 & $\begin{array}{l}\text { independent innovation of } \\
\text { scientific research project }\end{array}$ & $\begin{array}{l}\text { teachers guide students to apply for } \\
\text { independent innovation research } \\
\text { projects on campus and in the hospital } \\
\text { plan, mobilize the enthusiasm of } \\
\text { students' Autonomous Learning }\end{array}$ \\
\hline 4 & $\begin{array}{l}\text { to participate in their daily } \\
\text { activities of scientific } \\
\text { research [8] }\end{array}$ & $\begin{array}{l}\text { discussion with teachers, students, } \\
\text { cultivate the spirit of teamwork }\end{array}$ \\
\hline 5 & $\begin{array}{l}\text { the "production, learning and } \\
\text { research," a combination of }\end{array}$ & $\begin{array}{l}\text { students participate in the production } \\
\text { of the enterprise and innovation work } \\
\text { in the practice process, the cultivation } \\
\text { of innovative consciousness and } \\
\text { innovative ability in practice }\end{array}$ \\
\hline
\end{tabular}

Research on the Reform of Teaching Methods. In order to improve the quality of classroom teaching, to arouse the students' interest in specialized course, using a variety of teaching methods, such as lecture based, supplemented by self-study discussion class discussion, improve students' learning professional class interest [9]; the application of interactive teaching mode, based on heuristic, question teaching makes students to participate actively in the classroom, building a harmonious classroom; use of multimedia teaching means, enrich the teaching content, improve teaching effect [10]; make full use of the Internet to guide students to search for information, the Internet and VCD video combination, combination of theoretical courses and practical courses, active exploration of new knowledge, new ideas fields, increase research and exploration of the subject interest; regular lectures, combined with the teaching contents, inviting the industry have a certain visibility or work has been in the industry and technical personnel to carry out thematic speech is development trend of professional issues, industry, enrich the content of classroom 
teaching, enhance the effect of classroom teaching.

\section{Summary}

Strengthening the construction of curriculum group through the above measures, forming a unified, efficient fermentation course group, prominent biological engineering specialty in our college characteristics, and comprehensively improve the students ability of practice application of professional quality, engineering and scientific research innovation ability, so that students in the future employment and further studies have enough competitiveness

\section{References}

[1] X.H. Wang, J.C. Chen and D.Y. Liu. Discussion on the teaching reform in the course of fermentation technology[J]. Education and teaching research.Vol. 23 (2009) No.8, p.100.

[2] Y.J. Lang, C.Y Nie, Y.T. Zhang etc. Teaching experience and teaching reform in principles of fermentation technology course [J].Anhui Agricultural Sciences, Vol. 40 (2014) No.32, p.16001.

[3] M. Lu, L.J Xi, X.M. Chen etc. Consideration of corrosion and protection of thermal power equipment course teaching[J]. Journal of Northeast Dianli University.Vol. 33 (2013) No.4, p.79.

[4] Q. Wei, Y.P. Jia, S. Zheng etc. Biological technology comprehensive experiment' s teaching reform and practice based on the mode of application type innovative talents training

[J]. Journal of Northeast Dianli University, Vol. 33 (2013) No.4, p.91.

[5] G.J. Su, Q.H. Mo, Y.X. Yan etc. Synthetic experiment of bioengineering independent course and teaching reform[J]. Research and exploration in laboratory.Vol. 27 (2008) No.7, p.107.

[6] Y. Wu. Discussion on the teaching reform in the course of fermentation technology[J]. Bulletin of Microbiology Vol. 34 (2007) No.2, p.376.

[7] C. Guan, F. Zuo, X.J. Li etc. "The research and practice of teaching in the course of fermentation process with students as the center" $[\mathrm{J}]$. Agricultural products processing, Vol. 8 (2013) No.8, p.129.

[8] Q.X. Zhao, Y.H. Liu, Q. Wei etc. Research and Practice on the reform of biological experiment technology [J]. Journal of Northeast Dianli University, Vol. 30 (2010) No.3, p.27.

[9] W.P. Wang. Discussion on teaching reform of wine brewing technology[J]. Anhui Agricultural Science Bulletin, Vol. 13 (2007) No.20, p.140.

[10] Teaching reform and practice in brewing technology application and innovation talents training based on Science [J]. Chinese brewing, Vol. 32 (2013) No.5, p.168. 